\title{
Spatial Pattern of Burglary in South Yorkshire Using Geographic Information System (GIS)
}

\author{
Gaylan Rasul Faqe Ibrahim \\ Geography Department, Faculty of Arts, Soran University, Soran City, Erbil, Kurdistan Region, Iraq
}

\section{Email address:}

g01031983@gmail.com

\section{To cite this article:}

Gaylan Rasul Faqe Ibrahim. Spatial Pattern of Burglary in South Yorkshire Using Geographic Information System (GIS). International Journal of Astrophysics and Space Science. Vol. 4, No. 1, 2016, pp. 1-11. doi: 10.11648/j.ijass.20160401.11

\begin{abstract}
Burglary is an offence committed against others' property and it is considered a violent crime. Nowadays to monitor and detect burglary crime geographic information system (GIS) is used broadly. The aim of this study is to analyses spatial pattern and spatial dependency of burglary in the study area by applying GIS techniques. For understanding the crime pattern better and creating plans for preventing and reducing crime and using the resources and places, sometimes might make greatest differences; the identification of hotspots in time is very important. The data for this study obtained from the secondary data; boundary shape file of the study area, socioeconomic data and burglary data for November 2012 were gained. The outcome of the study shows that the distribution of burglary is clustered. It is clear from the results that the rate of burglary strongly affects the percentage of unemployed people; also the percentage of non-white and young people (aged 20-24) does not significantly correlate with burglary.
\end{abstract}

Keywords: Crime, Burglary, Spatial Pattern, GIS, South Yorkshire

\section{Introduction}

'Crime analysis is the systematic study of crime and disorder problems as well as other police-related issues-including sociodemographic, spatial, and temporal factors to assist the police in criminal apprehension, crime and disorder reduction, crime prevention and evaluation' (Santos, 2012, p. 2).

The field of crime analysis was invented at the beginning of nineteenth century by the London Metropolitan Police (Santos, 2012). The United States (US) National Institute of Justice's Crime Mapping Research contributed significantly to the novelty and widespread of crime analysis in many developed like countries like Australia and South America (Chainey and Ratcliffe, 2005). The main purpose of this study is to analyze spatial pattern of burglary in South Yorkshire using Geographic Information Systems (GIS) techniques. The rest of the report is organized as follows. Section two focuses on reviewing existing literature, section three discusses the methodology for this study while section four analyses spatial pattern of burglary. Section four discusses results of the analysis and section concludes the report.

\subsection{Explanation of the Topic}

This current study focuses on identifying spatial pattern of burglary in South Yorkshire using based techniques. The study analyses burglary data for November obtained from the South Yorkshire website and map examines its distribution using spatial auto-correlation concept in GIS environment. Density of burglary per 1000 households was mapped in order to examine rates of victimization of a household in the study and spatial cluster of burglary was mapped using kernel density estimation so as examine areas of higher than average concentration of burglary. Finally, socioeconomic variables like ethnicity, age groups, education attainment and occupation was mapped in order to analyse spatial heterogeneity and dependency of burglary. The topic is valuable and worthy of researching because earlier studies (Ratcliffe, 2004; 2002; Santos, 2012) have the valuable of crime mapping in policing management and decision makings.

\subsection{Study Justification}

In a British survey of 2009/10, total crime rates in England and Wales dropped by eight per cent in 2009/10 while burglary rates in South Yorkshire has declined by $11 \%$ with 7 rates per 1000 households (The Guardian, 2010). Despite recent significant declined in burglary rates, the South Yorkshire police authority and their partner organizations lunched Closed 
Circuit Television (CCTV) to assist them in 'reducing and detecting' burglary as well as reducing the fear of victimization (South Yorkshire Police, 2012). However, more efforts are required by the police authority to maintain the low burglary rates and even further reduce the burglary rates to the minimum level like identifying spatial pattern of burglary. Previous literature (Ratcliffe, 2004; Chainey and Ratcliffe, 2005; Brunsdon et al, 2007 and Chainey et al, 2008) have demonstrated that identifying crime pattern assist the policing authority to understand places with high cluster of crime and allocate ideal resources to those areas since police resources are limited. This study is aimed at identifying spatial pattern of burglary in the study area and therefore it is worthy of investigating because it will assist the policing authority in strategy burglary reduction planning and managing their resources because police resources are limited.

\subsection{Study Area}

South Yorkshire is a county in England. It comprises of four metropolitan areas that include Doncaster, Rotherham, Sheffield and Barnsley. South Yorkshire has 94 wards.

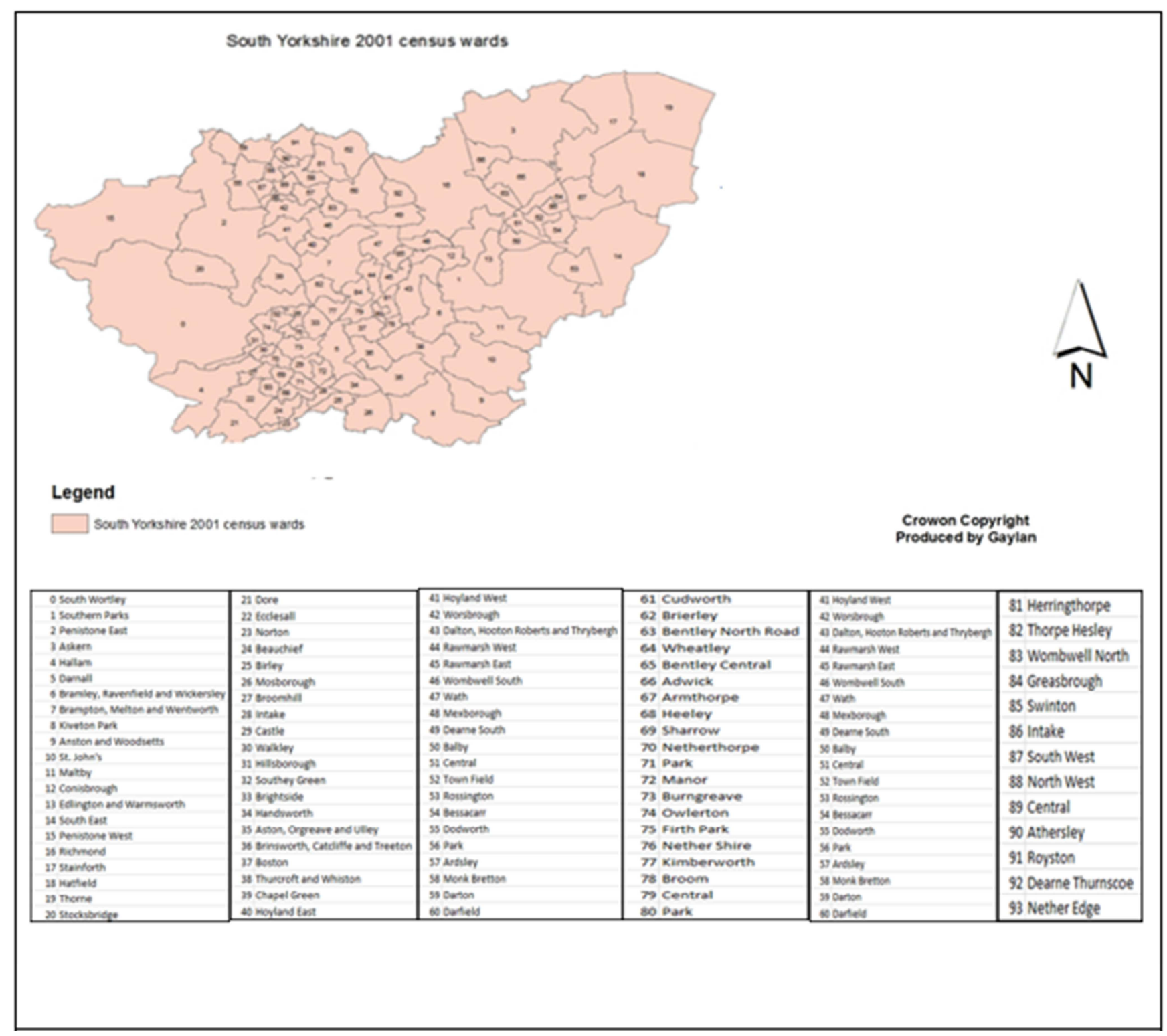

Fig. 1. Study area (South York Shire).

\section{Literature Review}

GIS application in crime mapping is widely spread. Declined in the prices of computer hardware and software, and availability of digital police crime data have resulted to the broad applications of GIS concept in crime mapping
(Chainey and Ratcliffe, 2005). Various theories of environmental criminologists (Santos, 2012; Thomas and Znaniecki, 2012; Nagin and Peternoster, 1993) have explained occurrence of crime based on environmental and behavioral factors that led to the opportunities for perpetrating crimes in space and time. These theories include the rational choice, the crime pattern, the social 
disorganization and the routine activity theory. According to Santos (2012) crime pattern theory observed that crime activities prevail as a result of interaction between activities of potential perpetrators and activities of potential victims in space and time. The rational choice theory emphases on circumstances that influence individual propensity to commit a crime based on perceived benefits and risks involved (Nagin and Peternoster, 1993). The social disorganization theory considers individual locality or neighborhood type as a key predictor of crime and defines crime as outcome of social interactions. The social disorganization theory posited that neighborhood type affects individual's ability to commit or not to commit a crime (Thomas and Znaniecki, 2012). The routine activity theory observes that variation in people daily activities improves opportunities for perpetrating a crime like burglary (Santos, 2012).

Burglary rates are not evenly distributed. Winchester et al (1982) state that burglary clustered around or in deprived neighborhoods. They examined risk of burglary in Sheffield and explored that burglary concentrations cluster around privately rented dwellings and terraced housing. Similar study was conducted in Manchester and found that burglary risk cluster around council flats (Winchester et al, 1982). Akins (2006) examined relationship between burglary and racial segregation in 340 American cities. Akins (2006) finding revealed that percentage of young male population does not significantly correlates with burglary while deprivation positively and significantly predict burglary. Carmichael and Ward (2000) examined relationships between youth unemployment and crime in the England regions and Wales using statistical method. They revealed that unemployment positively and strongly correlates with burglary and percentage of non-white ethnic group does not significantly correlates with burglary. This study will examine spatial pattern of burglary as well as spatial dependency or heterogeneity with burglary and other socioeconomic variables.

\section{Research Method}

This study applies GIS-based techniques in analysing spatial pattern and spatial dependency of burglary in the study area. The methods include spatial autocorrelation in order to examine spatial distribution of burglary in the study area, thematic mapping of burglary in order to map distribution of burglary, kernel density estimation for examining cluster of burglary and burglary density mapping in order to map risk of victimization for a household. The analysis of this study entails mapping of socioeconomic variables In order to examine spatial heterogeneity and dependency of burglary.

\subsection{Research Methodology}

Table 1. Crime mapping techniques.

\begin{tabular}{|c|c|c|}
\hline $\begin{array}{l}\text { Methods of crime hot } \\
\text { spots mapping }\end{array}$ & advantages & limitations \\
\hline Thematic mapping & $\begin{array}{l}\text { It is one of the most widely applied techniques. Williamson et al. } \\
\text { (2001) have revealed that geographical boundary themaptic map } \\
\text { is easier and quicker to identify crime hot spots even by an } \\
\text { unskilled analyst. }\end{array}$ & $\begin{array}{l}\text { 'Geographic areas of various sizes and shapes, when } \\
\text { aggregated and thematically shaded can be misleading. } \\
\text { For example map reader's attention to be drawn to the } \\
\text { large area that are broadly shaded'(Chainey and } \\
\text { Ratcliffe, 2005, p. } 151 \text { ) }\end{array}$ \\
\hline Grid thematic mapping & $\begin{array}{l}\text { Chainey and Ratcliffe ( } 2005) \text { state that grid thematic mapping } \\
\text { gives better visualization of the spatial crime pattern when ideal } \\
\text { cell resolution is selected. }\end{array}$ & $\begin{array}{l}\text { Processing grid thematic map is time consuming and big } \\
\text { sizes of files. The output map can be misleading when } \\
\text { high resolution grid is applied. }\end{array}$ \\
\hline Point mapping & $\begin{array}{l}\text { Chainey and Ratcliffe (2005) have posited that point mapping is } \\
\text { useful in visualizing few number of crime incidents and mapping } \\
\text { repeat victimization of burglary. This technique is not ideal for } \\
\text { this study because it is restricted t small number of crime events. }\end{array}$ & $\begin{array}{l}\text { According to Brunsdon et al (2005) crime events cluster } \\
\text { in particular location when and identify hot spots can be } \\
\text { hard applying this technique to map huge number of crime } \\
\text { data. }\end{array}$ \\
\hline $\begin{array}{l}\text { Kernel density } \\
\text { estimation (KDE) }\end{array}$ & $\begin{array}{l}\text { A KDE output map enable better interpretation of spatial crime } \\
\text { cluster as compare to other traditional methods like point map, } \\
\text { grid thematic map, thematic and geographic thematic maps } \\
\text { (Chainey and Ratcliffe, 2005). KDE map shows more accurate } \\
\text { location, relative scale and spatial distribution of crime hot spot } \\
\text { (op cit). AS a result of the above benefits of KDE, this study } \\
\text { applies KDE method in analysing burglary hot spots. }\end{array}$ & $\begin{array}{l}\text { KDE technique is influenced by lack of statistical strength } \\
\text { (Chainey and Ratcliffe, 2005). }\end{array}$ \\
\hline
\end{tabular}

KDE method is the most appropriate technique for analyzing burglary hot spots in the study area due to the above advantages of the technique over others as mentioned in table 1 above.

Moran's I.

Moran's I index estimate spatial distribution of crime data which cluster, disperse or random across a geographic unit
(Santos, 2012). It is a standard measure of global spatial dependency, which can be applied to polygons, or points that have attribute data attached to it (Chainey and Ratcliffe, 2005).

'The advantage of Moran I over nearest neighbour is that while nearest neighbour analysis allow analyst to measure clustering in points, Moran's I can show if there is significant clustering in a variable' (Chainey and Ratcliffe, 2005, p. 130). 
The above benefits of Moran's I, justifies the suitability of Moran's I over nearest neighbour for this study.

\subsection{Data}

This study obtained data from the secondary sources. Boundary shapefile of the study area was extracted from the UKBoarder, burglary data for the month of November were obtained from the South Yorkshire Police website. Socioeconomic data were collected from the 2001 UK census records.

\subsection{Data Weakness}

The police data is primarily the main source of data for this study but it is argued that not all crime events are been report to the police and therefore the Police data is not comprehensive (Home office, 2012). This constraint of police data affects the strength of this research. The UK 2001 census data used for this study is outdated, for more than ten years that shows that some information may possibly change but 2011 census is not yet released for public usages. The used of UK 2001 census data is one the key limitations of this study because it does not reflect current statistics. The 2001 census wards are associated with modifiable area unit problem at both scale and zonally level. Openshew (1984) observed that administrative boundary are been influenced by MAUP related issues at zones and scale level. The aggregate statistical data does not represent the underlying factors and the polygons or census boundaries have being designed and cannot be altered.

\subsection{Rationale for Variables Selection}

Table 2. Justification for selecting data.

\begin{tabular}{|c|c|}
\hline Data chosen for the study & Justification \\
\hline Burglary data for the month November 2012 & It was the most recent burglary data available on the police website. \\
\hline UK 2001 Census data at ward level & $\begin{array}{l}\text { Comparative researches (Martins, 2000; Mesev 1998; Stillwell and Duke-Williams 2007) have posited } \\
\text { that census data is the most comprehensive, consistent and complete source of socioeconomic data in the } \\
\text { UK. Openshaw (1984) has observed that administrative boundaries like census tracts, wards and output } \\
\text { area units are associated with modifiable areal unit problems (MAUP) therefore it is paramount to adopt } \\
\text { wards level data for this study because both ward and output area level have similar problem of MAUP } \\
\text { and interpreting result of } 92 \text { wards in the study area is better than interpreting the result large output area } \\
\text { of over } 1700 \text {. }\end{array}$ \\
\hline Percentage of non-white & Carmichael and Ward (2000) state that percentage of non-white negatively correlate with burglary. \\
\hline Percentage of people aged 20-24years & Akins (2006) revealed that percentage of young people does not significantly correlates with burglary. \\
\hline Percentage of people with no qualification & $\begin{array}{l}\text { Measures of deprivation and previous works (Winchester et al 1982; Buonanno and Montolio, 2008; } \\
\text { Kawachi et al, 1999) have documented the relationship between burglary and deprivation. }\end{array}$ \\
\hline Percentage of people with no car ownership & $\begin{array}{l}\text { Measure of low income because UK } 2001 \text { census record does not holds information on income and car } \\
\text { ownership is used to measure income as it is assume that people with high income can afford cars. } \\
\text { Income is a measure of deprivation and Kawachi et al. (1999 revealed that deprived neighbourhoods are } \\
\text { associated with higher crime rates. }\end{array}$ \\
\hline Percentage of unemployed & $\begin{array}{l}\text { Carmichael and Ward (2000) observed that strong positive relation exist between percentage of } \\
\text { unemployed people and burglary. }\end{array}$ \\
\hline
\end{tabular}

\section{Data Analysis}

\subsection{Spatial Autocorrelation}

\begin{tabular}{|r|r|}
\hline Global Moran's I Suminary \\
\hline Moran's Index: & 0.378091 \\
\hline Expected Index: & -0.010753 \\
\hline Variance: & 0.001048 \\
\hline z-score: & 12.009985 \\
\hline p-value: & 0.000000 \\
\hline
\end{tabular}

Fig. 2. Spatial autocorrelation. 


\subsection{Distribution of Burglary}

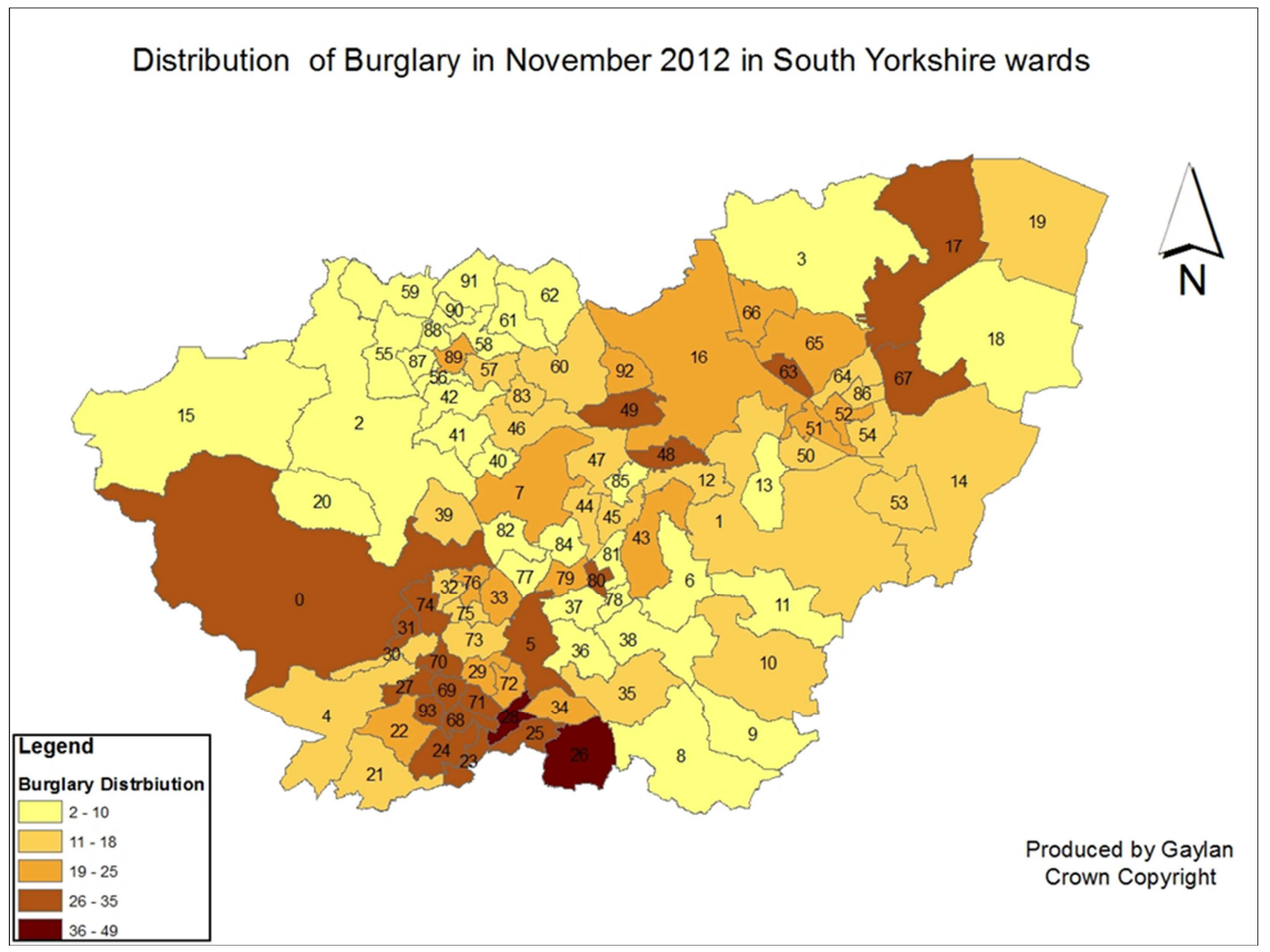

Fig. 3. Distribution of burglary.

\subsection{Burglary per 1,000 Households}

Burglary per 1000 households in November at South Yorkshire 2001 census wards

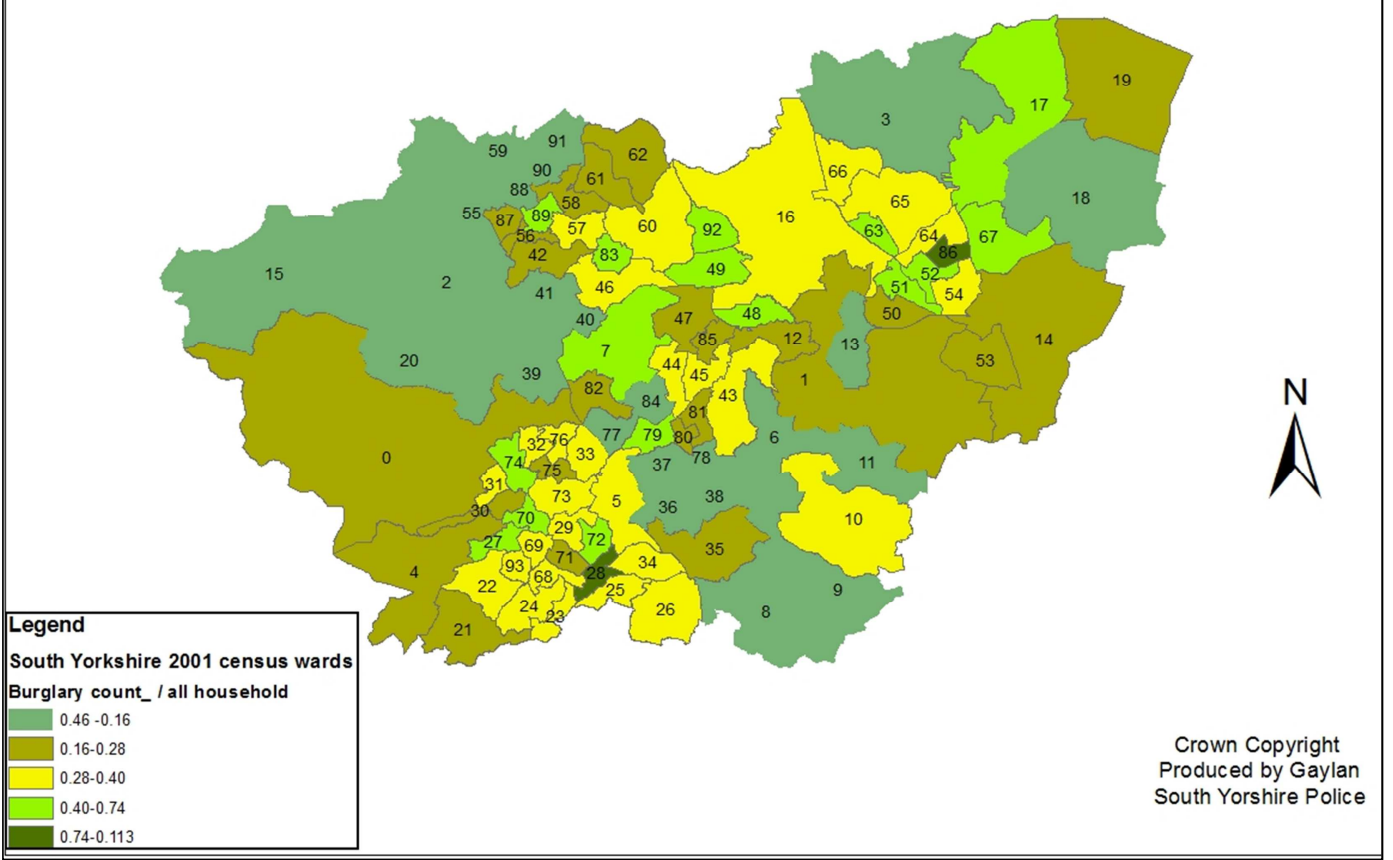

Fig. 4. Burglary density in South Yorkshire. 


\subsection{Hot Spot Mapping}



Fig. 5. Burglary hot spots.

\subsection{Choropleth Mapping of Socioeconomic Variables}

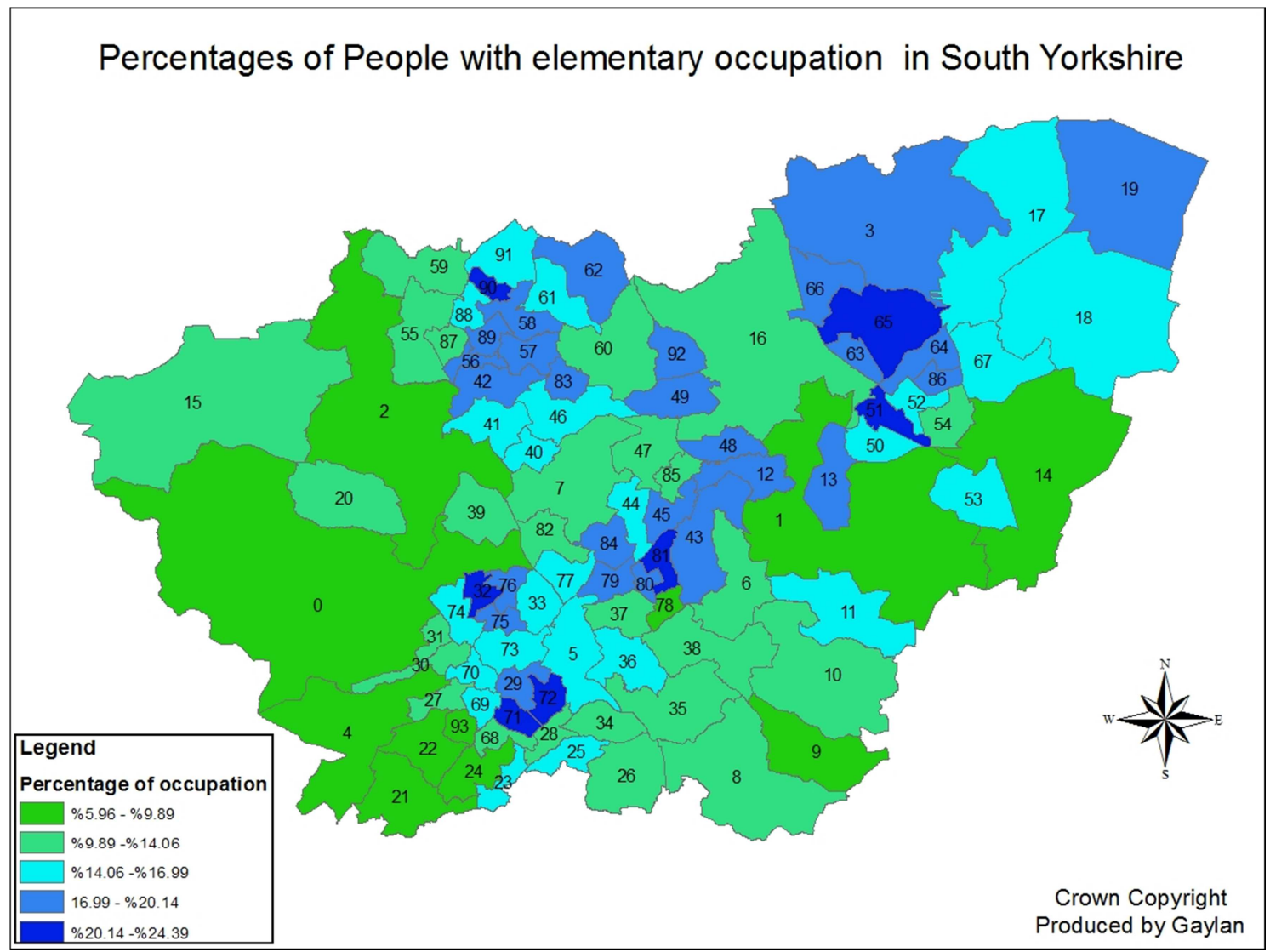

Fig. 6. Percentage of people with elementary occupation. 


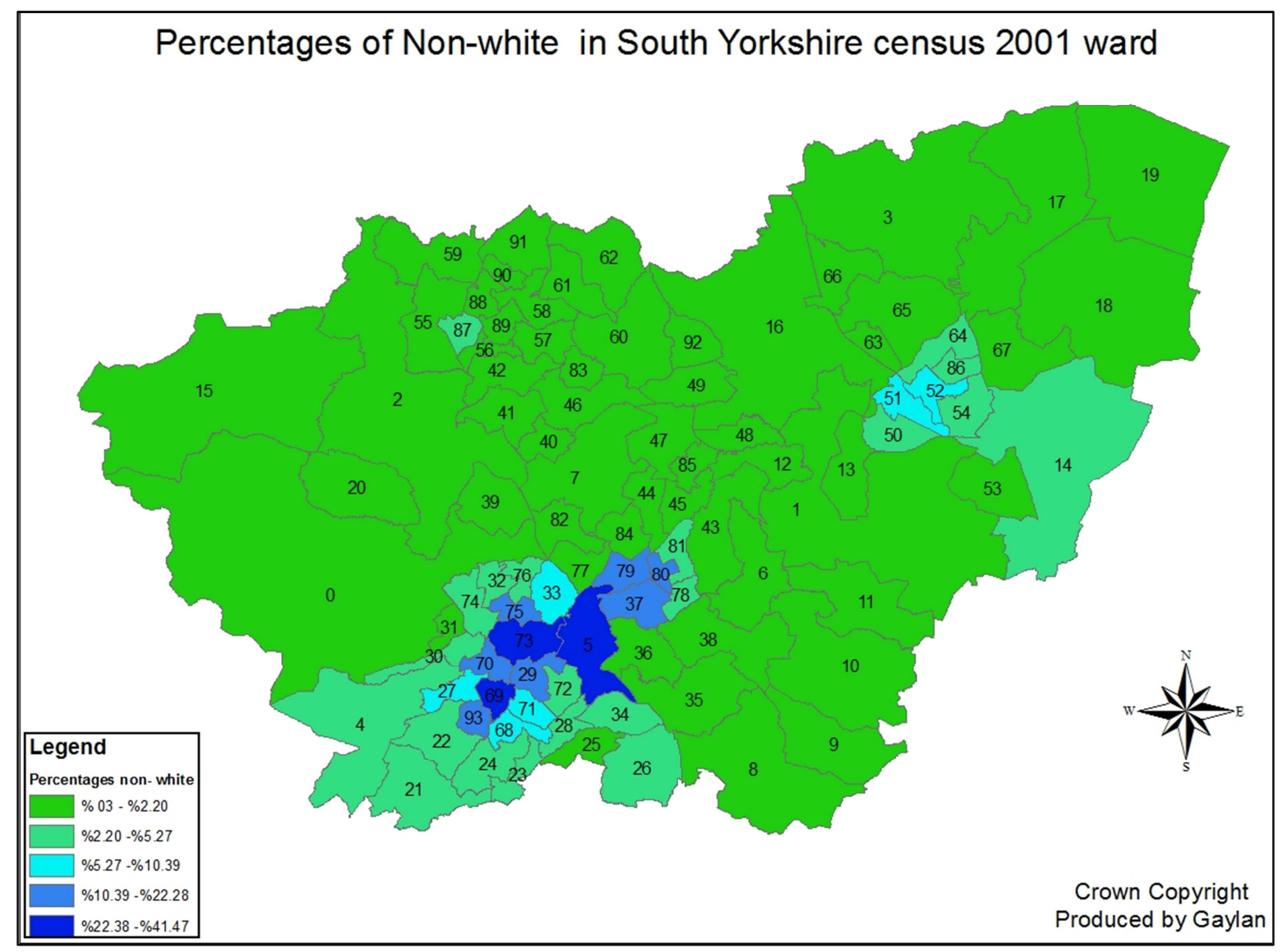

Fig. 7. Percentage of non-white.

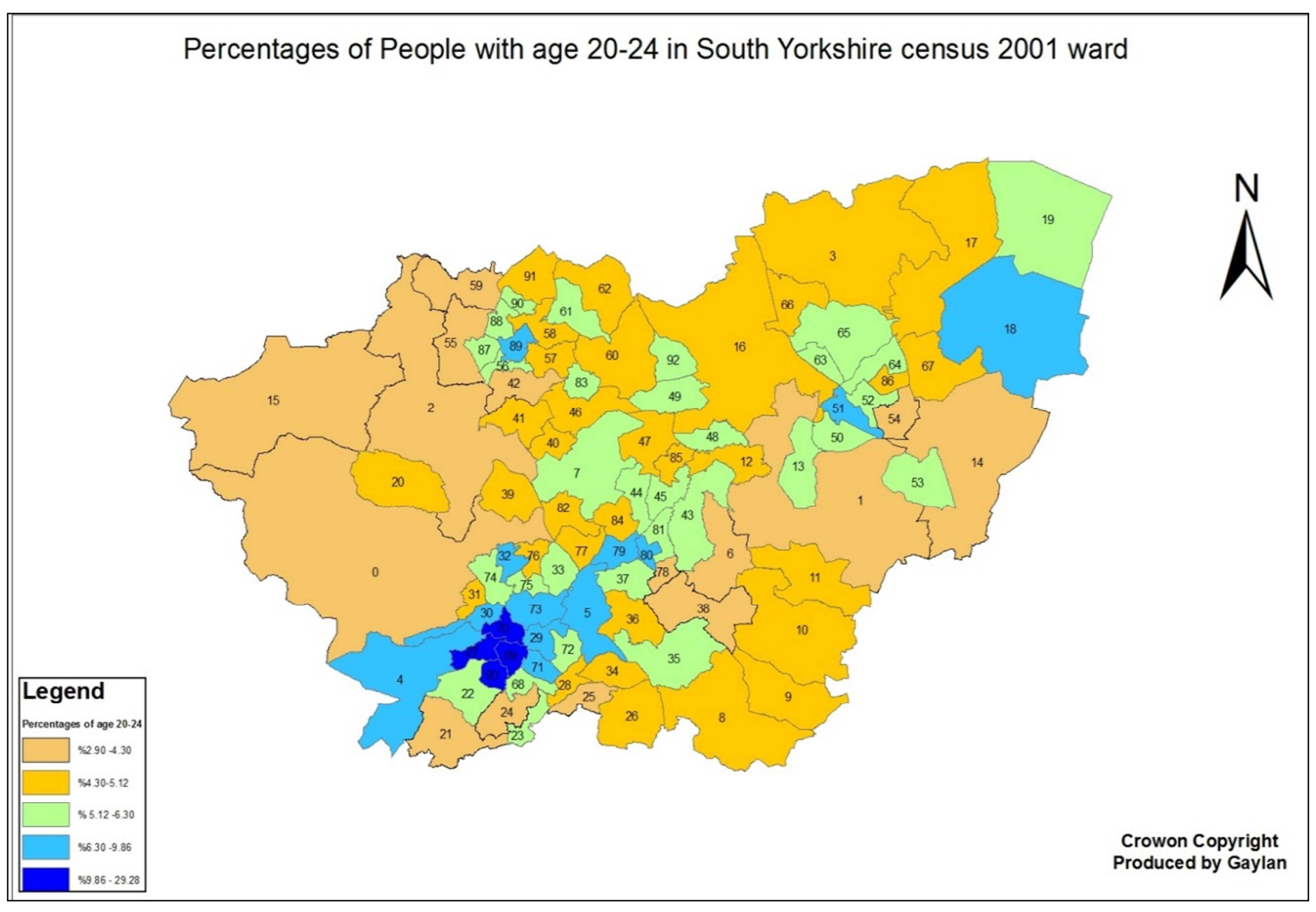

Fig. 8. Percentages of aged 20-24 years. 




Fig. 9. Percentages of people with no qualification.

Percentages of People without Car in South Yorkshire census 2001 ward

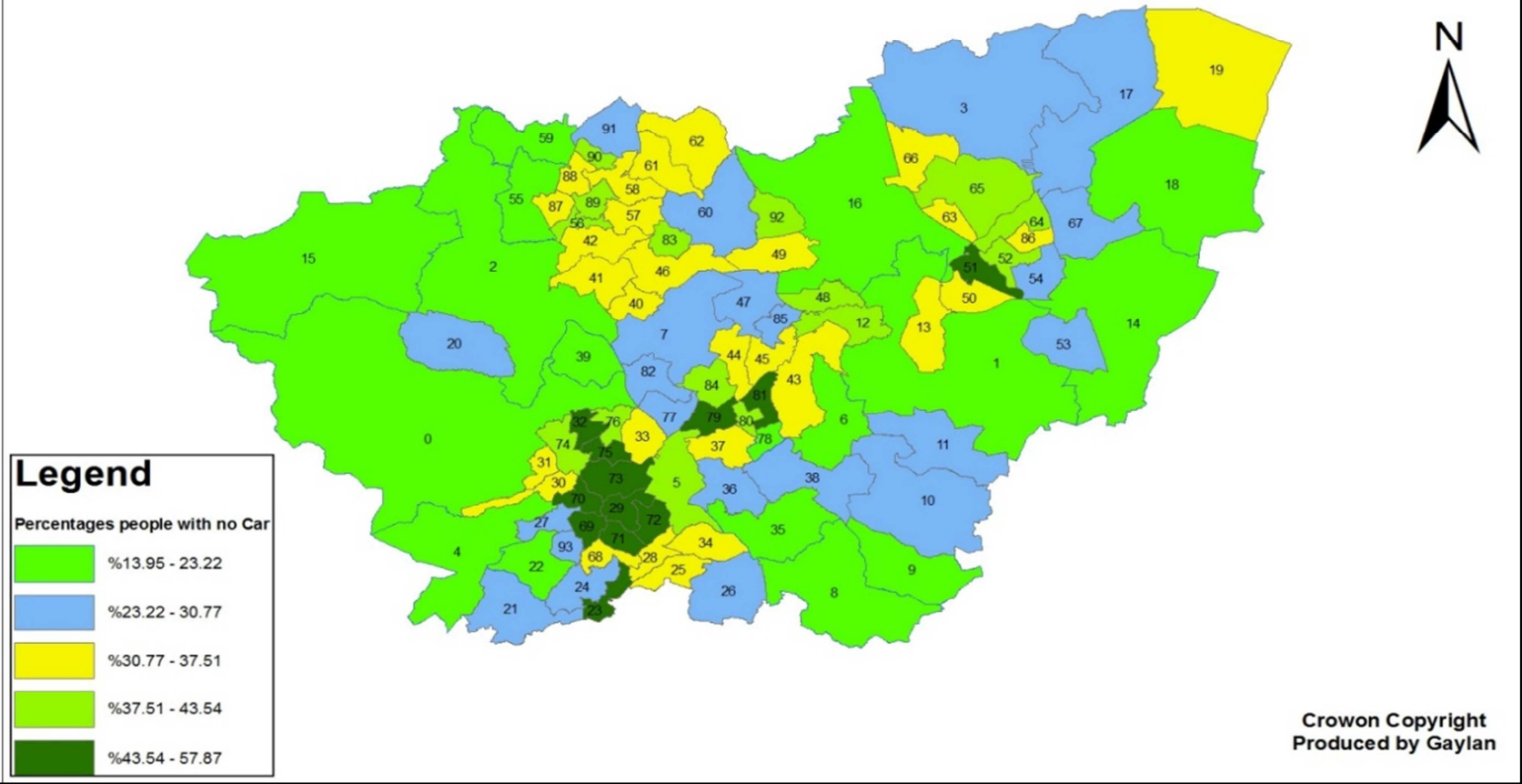

Fig. 10. Percentages of people with no car ownership. 


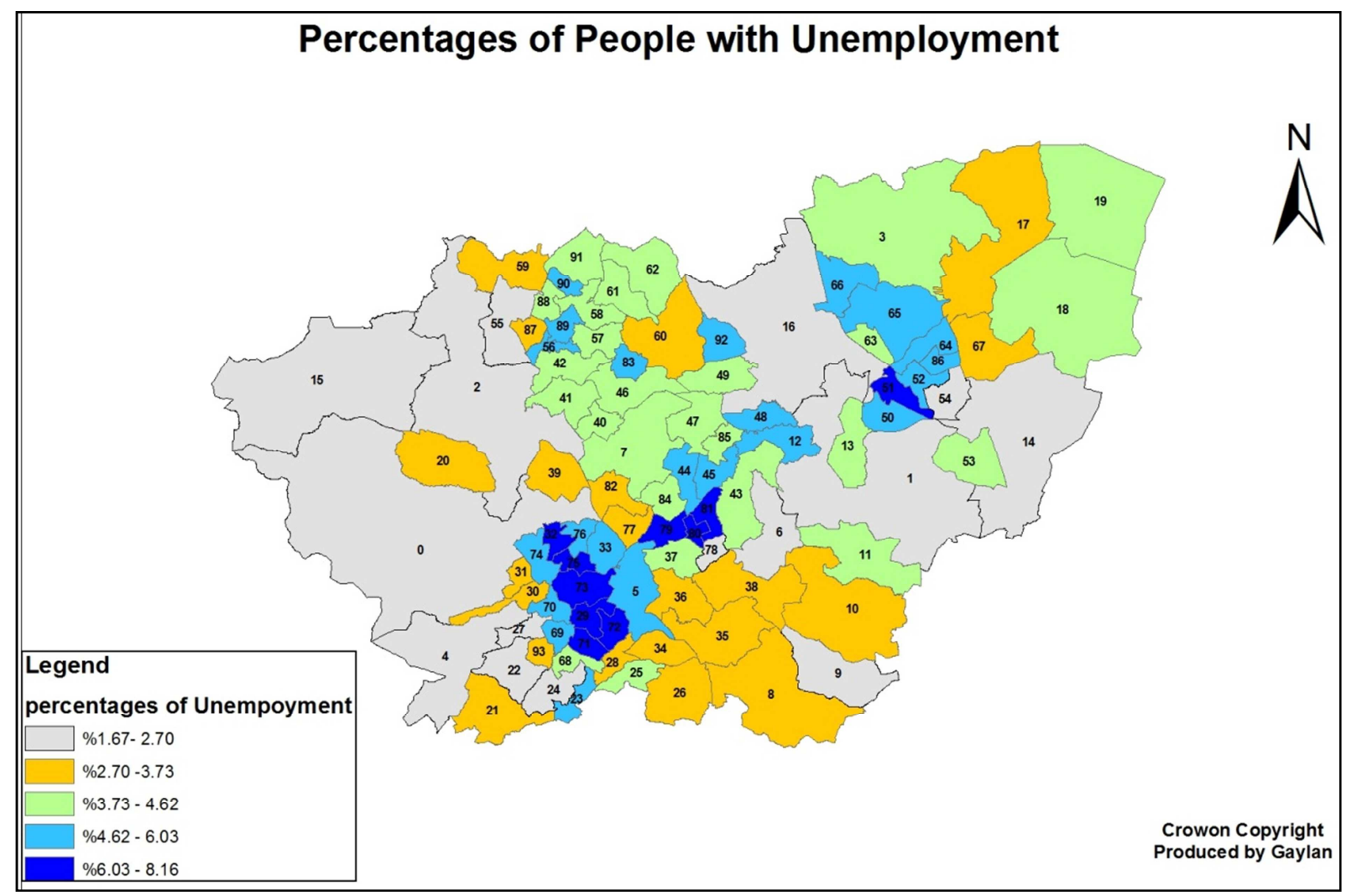

Fig. 11. Percentages of unemployed people.

\section{Discussion}

Global Moran's I summary in figure 2 shows Z-score value of 12.000, P-value of 0.000 and Moran's index of 0.3280 . P-value of 0.000 shows that the overall model is significant and Z-score of 12.000 indicates that distribution of burglary is clustered. Wards that show highest distribution of burglary of 36 to 49 in figure 3 were Intake and Mosborough while wards with the lowest distribution of burglary were Penistone East, Hatfield and Askerns among others. The thematic of burglary distribution just reflect burglary count not the density because it has not been normalized by the households. Burglary density map in figure 4 shows that wards with highest of victimization of burglary with 0.40 to 0.113 rates of 1000 households were Broomhill, Intake in both Sheffield and Doncaster, Town Field and Central and it implies that 1000 houses were 0.40 to 0.113 at great risk of been victims of burglary (see figure 4). Wards with the lowest 0.04 to 0.16 lowest rates of victimization were Chapel Green and Pennistone West among others (see figure 4). It means that 1,000 wards were 0.04 to 0.16 low rates likely to be burgled. The wards with high density burglary like Intake and Town Field were wards with high percentages of people elementary occupation of over $20 \%$ (see figure 6), high percentages of unemployed people over $6 \%$ in figure 11 and high percentages of people with no qualification of over $45 \%$ in figure 9 . This finding is consistent with the finding Winchester et al (1982) that observed that burglary cluster around deprived neighborhoods. Finding from Broomhill ward challenges the finding of Winchester et al (1982) because Broomhill ward is among the least deprived neighbourhood as it is characterized by low percentage of unemployed people $1.6 \%$ to $2.7 \%$ in figure 11 , low percentages of people with no cars in $13 \%$ to $23 \%$ in figure 10 and low percentage of people with no qualification of $0.3 \%$ to $2.2 \%$ in figure 9 but high density of burglary 0.46 to 0.113 in figure 4 . Broomhill ward insight disagrees with the finding Winchester et al (1982) might be because of proxy.

Burglary hot spot map in figure 5 displays Hallam, South Wortley, Penistone East, Richmond and Kiveton ward among others as areas with significantly low cluster of burglary crime cool spots with Z-score value of 0 to 0.8 .5 . Z-score value of 10 to 19 indicates high cluster of burglary hot spots in figure 5 and wards that shows significantly high clustered of burglary hot spots were Intake, Sharrow, Park, Nether Edge and Broomhill.

Wards that display significantly low cluster of burglary hot spots (see figure 5) like Hallam, Penistone East and South Wortley were characterized by $6 \%$ to $22 \%$ low percentages of people with no educational qualification (see figure 9), $0.3 \%$ to $2.2 \%$ low percentages of non-white people in figure 7 , low percentages of unemployed people of $1.6 \%$ to $2.7 \%$ in figure 11 , low percentages of people with no cars of $13 \%$ to $23 \%$ in figure 10 and low percentages of people aged 20-24 years of $2.9 \%$ to $4.3 \%$ in figure 8 . Wards that displayed low cluster of burglary hot spots in figure 5, like Park, Intake and Firth Park ward displayed low percentages of non-white people of $0.3 \%$ 
to $2.2 \%$ (see figure 7) except Broomhill and Sharrow displayed high percentages of non-white people of $22 \%$ and above. Intake, Park and Firth Park ward were wards of high percentages of unemployed people of above $6 \%$ in figure 11 but Broomhill and Sharrow ward displayed low percentages of unemployed people of $1.6 \%$ to $2.7 \%$ but high cluster of burglary hot spot. Park and Firth Park ward were characterized by high percentages of people with no cars of $43 \%$ and above while Broomhill and Sharrow displayed low percentages of people without cars of $13 \%$ to $23 \%$ in figure 10 .

Insights from this study revealed that deprived wards like Intake, Park and Firth Park have high cluster of burglary hot spot in figure 5, is consistent with the theory of social disorganization which states that neighbourhood type affects person propensity to commit a crime and as a result, deprived areas tend to have higher crime rates than affluent neighbourhoods (Thomas and Znameck, 2012). The finding from Broomhill and Sharrow ward that were among the least deprived wards but show high clustering of burglary hot spots challenges the theory of social disorganization in Thomas and Znameck (2012) and (Akins, 2006; Wincester et $a l, 1982)$ that consistently revealed that high rates of burglary cluster around deprived wards. Broomhill and Sharrow ward deviating from the findings of these previous works could be as a result of proxy effect.

Evidence from the study discloses that low cluster of burglary cool spots (see figure 5) like South Wortley and Hallam among others were wards of $1.6 \%$ to $2.7 \%$ of unemployed people in figure 11 . This finding agrees with the finding of Carmicheal and Ward (2000) that observed that percentages of unemployed people strongly and positively predicts burglary. The unique insight from this investigation that Intake, Park and Firth Park were wards of low percentages of non-white people of $0.3 \%$ to $2.2 \%$ in figure 7 but show high cluster of burglary hot spots with Z-score of 10 to 19 (see figure 5) while Broomhill and Sharrow were wards of above $6 \%$ of non-white but show significant cluster of burglary hot spot with Z-score between 10 to 19 (see figure 5), agrees with the finding of Akins (2006) that posited that percentage of non-white does not significantly correlates with burglary. This indicates that burglary has no spatial dependency with percentages of non-white persons. The evidence from the research indicates that wards of high percentages of people aged 20-24 years $9.8 \%$ in figure 8 like Broomhill and Sharrow shows high cluster of burglary hot spots (see figure 5) and also wards of low percentages of people aged 20-24 years like Park, Intake and Firth park (see figure 8) display high cluster of burglary hot spot this finding is consistent with the finding of Akin (2006) that revealed that percentage of young people does not significantly correlates with burglary. The evidence from this study reveals that burglary has no spatial dependency with percentage of people aged $20-24$ years.

\section{Conclusion}

The insight from this research (Moran's I) reveals that distribution of burglary is clustered (see figure 2). Evidence from the current investigation has shown that burglary density clustered around deprived neighbourhoods like Central and Intake but a least deprived ward (Broomhill) appeared to have high risk of burglary (see figure 3 ). This indicates that burglary risk of victimization could happen in both deprived and affluent wards. Affluent wards like Pennistone East and Chapel Green displayed low risk of burglary in figure 3 . Hot spot of burglary appeared to be significantly high most deprived wards like Park, Intake and Town Field and even some least deprived wards like Broomhill in figure 5. Least deprived wards like Hallam, Penistone West and South Wortley among others were to be wards of significant low cool spots of burglary.

\section{References}

[1] AKINS, S. (2003). Racial segregation and property crime: Examining the mediating effect of police strength. Justice quarterly, 20 (4), 675-695.

[2] BRUNSDON, Chris, CORCORAN, Jonathan and HIGGS, Gary (2007). Visualising space and time in crime patterns: A comparison of methods. Computers, environment and urban systems, 31 (1), 52-75.

[3] BUONANNO, Paolo and MONTOLIO, Daniel (2008). Identifying the socio-economic and demographic determinants of crime across Spanish provinces. International review of law and economics, 28 (2), 89-97.

[4] CARMICHAEL, F. and WARD, R. (2000). Youth unemployment and crime in the English regions and wales. Applied economics, 32 (5), 559-571.

[5] CHAINEY, S. and RATCLIFFE, J. (2005). GIS and crime mapping. Wiley.

[6] Home Office (2012). A new approach to fighting crime. [online]. Last accessed 20 October 2012 at: http://www.jdi.ucl.ac.uk.

[7] KAWACHI, I., KENNEDY, B. P. and WILKINSON, R. G. (1999). Crime: Social disorganization and relative deprivation. Social science \& medicine, 48 (6), 719-731.

[8] MARTIN, D. (2000). Towards the geographies of the 2001 UK census of population. Transactions of the institute of British geographers, 25 (3), 321-332.

[9] MESEV, V. (1998). The use of census data in urban image classification. Photogrammetric engineering and remote sensing, 64 (5), 431-436.

[10] NAGIN, D. S. and PATERNOSTER, R. (1993). Enduring individual differences and rational choice theories of crime. Law \& soc'y rev., 27, 467.

[11] OPENSHAW, S. (1983). The modifiable areal unit problem. Geo Books Norwich. 38.

[12] RATCLIFFE, J. H. (2002). Aoristic signatures and the spatiotemporal analysis of high volume crime patterns. Journal of quantitative criminology, 18 (1), 23-43. 
[13] SANTOS, R. B. (2012). Crime analysis with crime mapping. Sage Publications, Incorporated.

[14] South Yorkshire Police (2012). NOT PROTECTIVELY MARKED SOUTH YORKSHIRE POLICE [online]. Last accessed 17th January 2013 at: http://www.southyorks.police.uk.

[15] SOUTH YORKSHIRE POLICE (2012). Police crime data. [online]. Last accessed November 2012 at: http://www.police.uk/data.

[16] STILLWELL, J. and DUKE-WILLIAMS, O. (2007). Understanding the 2001 UK census migration and commuting data: The effect of small cell adjustment and problems of comparison with 1991. Journal of the royal statistical society: Series A (statistics in society), 170 (2), 425-445.
[17] THE GUARDIAN (2010). Crime statistics: Get the rates where you live. [Online]. Last accessed 15th January 2013 at: http://www.guardian.co.uk/.

[18] THOMAS, W. I. and ZNANIECKI, F. (2012). Social disorganization theory.

[19] WILLIAMSON, D., MCLAFFERTY, S., GOLDSMITH, V., MOLLENKOPF, J AND MCGUIRE, P., (1999). 'A better method to smooth crime incident data', ESRI news. [online]. Last accessed 20 January 2013 at: http://www.esri.com.

[20] WINCHESTER, S., JACKSON, H. and BRITAIN, G. (1982). Residential burglary: The limits of prevention. HM Stationery Office. 